\title{
From Coping with Stress to Positive Coping with Life: Theoretical Review and Application
}

\author{
Elías A. Góngora-Coronado, Iris I. Vásquez-Velázquez \\ Universidad Autónoma de Yucatán, Mérida, Mexico \\ Email: gcorona@correo.uady.mx
}

How to cite this paper: Góngora-Coronado, E. A., \& Vásquez-Velázquez, I. I. (2018). From Coping with Stress to Positive Coping with Life: Theoretical Review and Application. Psychology, 9, 2909-2932. https://doi.org/10.4236/psych.2018.915169

Received: November 8, 2018

Accepted: December 21, 2018

Published: December 24, 2018

Copyright (c) 2018 by authors and Scientific Research Publishing Inc. This work is licensed under the Creative Commons Attribution International License (CC BY 4.0).

http://creativecommons.org/licenses/by/4.0/

\section{(c) (i) Open Access}

\begin{abstract}
This paper is a review and analysis of the theoretical evolution of the concept of coping with stress to a more positive way of coping, as well as an example of application. The main results of an integrated research in three phases about the nature and practice of a more positive coping with life are presented (Góngora-Coronado, 2010). The first phase is to explore its nature in a qualitative manner. A second phase is to study the relationship of direct-reappraisal coping (Góngora-Coronado, 2000; Reyes-Lagunes, 2011), with happiness, mindfulness and spirituality, which are positive variables, to explore their nature more accurately, and a third phase, is for the exercise and practice of a more positive coping, with an intervention program. The participants for each phase were: phase 1:50; phase 2:306; and phase 3:32. Relevant instruments, psychometrically valid in the context of culture, were applied. The results in each of the phases provide information about the nature of a more positive coping, as well as the benefits of its systematized practice. It concludes with the importance of linking theory with practice for a more positive coping and a happier life.
\end{abstract}

\section{Keywords}

Coping, Positive Coping, Theoretical Review, Application

\section{Introduction}

\subsection{Theoretical Revision}

Current research mentioned in the literature of concepts related to the process of adapting to life such as psychological stress, coping and health is impressive in its breadth, depth and complexity (Folkman, 2011), which has changed the way in which we can see the health and understand the skills for adaptation (Aldwin, 2011; Buskits \& Davis, 2007). 
Generally speaking, until a few years ago, the study of the psychological characteristics had been focusing on the negative aspects of the phenomenon (Seligman \& Csikszentmihalyi, 2000) such as the concept of coping (Folkman, 2011; Rabinowitz \& Arnett, 2013). The systematic study of all the positive things that humans can do to enjoy life and realize that with all its problems life is worth living, has been left out (Csikszentmihalyi \& Csikszentmihalyi, 2006; Pawelski \& Moores, 2013).

Fortunately, nowadays, to see the human being in a complete view and making a strong emphasis the scientific study of all its positive aspects has been gaining momentum (Seligman, Railton, Baumeister, \& Sripada 2016; Zautra \& Reich, 2011).

The positive psychology movement has been of great help to this integral advance and progress in psychology (Seligman \& Csikszentmihalyi, 2000; Snyder \& López, 2002, 2007), which has been proposed among its objectives "to understand positive emotion, build strength and virtue and provide guideposts for finding what Aristotle called the good life" (Seligman, 2002: p. XI).

And therefore, recovering and focusing on a more comprehensive view (Aldwin, 2007; Folkman \& Moskowitz, 2004), bio-psycho-socio-cultural (Díaz-Guerrero, 2003) including the positive and prospective aspects of adaptation, not only understood as a balance in the sense of homeostasis, but as promotion or personal growth for wellbeing, and in the dimension of past, present and future time (Seligman et al., 2016). This context of the study of concepts leads to the theoretical relationship with other concepts of a more positive nature. For example, interestingly, it has been mentioned under this current view of the adaptation process, that there are conceptual similarities between emotional maturity, growth to cope with stress, and wisdom (Aldwin, 2011).

Thus, as the study of the concept of coping continues, it has also followed the progress of the original focus on the most negative aspects, to gradually focusing of the most positives concepts as well. At the beginning of this concept in psychology, there was a relationship between coping and defense mechanisms (Aldwin, 2011).

This theoretical work can be traced from the early psychoanalytic formulations and as part of the neo-analytical thinking of the 30s and 40s (Endler \& Parker, 1990; McCrae, 1984). In fact, there was a predominance of the clinical approach in the study of coping, in contrast to the little attention devoted to the social sciences.

This resulted in a great emphasis on circumstances that are potentially harmful to the wellbeing of people, and to emphasize the study of coping, as a highly individualized defense (Pearlin \& Shooler, 1978). In the clinical area, in which these ideas were formed, coping was subordinate to the defense, which is thought to be a largely unconscious process, and that stressors affecting a person were primarily intrapsychic conflicts (McCrae, 1984).

In the 60s, the researchers shifted their attention to the unconscious defense coping to the study of stress, and an extensive literature on the effects of stressful 
life events on physical and psychological health was fostered (Folkman, 1984; McCrae, 1984).

Most studies in this area attempted to show that individuals who had experienced a disproportionate number of important changes in their lives, were particularly susceptible to disease. However, with the progressive introduction of more accurate methodologies, it was decreasing the magnitudes of the observed correlations (Lazarus \& Folkman, 1984; McCrae, 1984).

As a result, researchers began to identify variables that could moderate or to be moderating the stress-illness relationship. In other words, they began to ask more what might help or interfere with adequate adaptation, rather than about physical or psychological effects of stressors. And in the following years, coping emerged as an important candidate in the investigation of these moderators (Billings \& Moos, 1981, 1984; Holahan \& Moos, 1990; Scheier, Carver, \& Bridges, 1994). The research led to conclude that, if individuals coped effectively with the problems that they face, it would enable them to reduce the harmful effects of stress (Lazarus \& Folkman, 1984; McCrae, 1984; Pearlin \& Shooler, 1978). This led, as McCrae (1984) points out, to some important changes:

First, most of the efforts about coping were conceived as responses to external stressors, such as illness, divorce, bereavement, or everyday problems, rather than responses to unconscious conflicts. Second, responses to stressors or problems were considered basically conscious strategies. And third, a major change in methodology was made. Researchers, rather than focusing on the clinical point of view to reveal the underlying conflict and interpret the defensive behavior, they tried to identify the stressor or source of the problem, and openly asked the individuals to report what they did to cope with stress or problems. This followed the trend of a more objective research that distinguished it from the work of past years.

As for the answers, strategies or types of coping, there have been many efforts to develop classification schemes. Though, as Billings and Moos (1984) point out, a common feature of many of these taxonomies has been the distinction between more active coping strategies or of approximation; and more passive strategies, that involve essentially the self-modification or avoidance, and include both behavioral and cognitive efforts to address the challenge, and manage threat assessment. Actually, there is somehow, a basic duality between activity-passivity, approach-avoidance; problem-emotion, or task-person. However, as Stone and Neale (1984) pointed out, despite the frequency with which the concept of coping has been used in the literature, there is no agreement about the types of its strategies.

Lazarus and Folkman (1984) identified two general forms of coping that have been taken into account in psychology. Regarding their roles, such ways make a difference between coping aimed at manipulating or altering the problem and coping aimed at regulating the emotional response generated by the problem. The first one is called problem-focused coping and the second one is emotion-focused coping. 
Researchers realized that the problems, although diverse in nature, whether catastrophic, unforeseen, uncontrollable, vital, daily stress or small setbacks, as Lazarus and Folkman called (1984), might be less important in itself for the individual's wellbeing rather than how they are perceived and how they face these problems (Aldwin \& Revenson, 1987). In other words, it could be said that the problem is not whether we have or not have problems, but what do we do with the problems we have (Góngora-Coronado, 2000).

As to the meaning of this concept of coping with stress, among the various definitions that have been proposed, Latack and Havlovick (1992) found, over 25 years ago, in an extensive review of the literature, that there is a convergence in them, and it is the coincidence that it is part of a transaction "environment-person" that occurs when a stressful situation is evaluated. In a more recent review, Seiffge-Krenke (2011) proposes that coping is an active and proactive process to respond to stimuli that are evaluated as surpassing or exceeding the person's resources. This is very similar to the aforementioned convergence and that comes very close to the definition that had been proposed before by Folkman and Lazarus (1980), in which the perception of a situation as stressful prevails.

Research has confirmed, with increasing consistency, the complexity and multidimensionality of this concept, and that its nature supposes a dynamic process; sensitive both to the demands of the environment and to resources of the individual, as well as to the provisions of the personality. In all of which the perception and evaluation of the event is key, in relation to the control (Góngora-Coronado, 2000).

This construct is considered in the present, and very consistently, as a factor that mediates the relationship between stress and adaptation, or physical or mental disorder, and is recognized as a central role in this process of stress (Lazarus, 2006; Skinner \& Zimmer-Gembeck, 2011).

The interest in this topic has been growing in the past 40 years, and there has been a dramatic proliferation of research across the social and behavioral sciences (Folkman, 2011) and public health (Buskits \& Davis, 2007). Many researchers began their investigation with the hope that the concept of coping could help to explain why some individuals do better than others when facing stress or problems in their lives.

Little by little, the point of view increased, that was more than knowing about the stress and distress of the people, but it was more productive to study how people face their circumstances, in order to help them to focus on a better quality of life (Frydenberg et al., 2003).

The psychological study of this concept has concluded that it is a complex, dynamic, reciprocal process and closely linked to different personality traits. It must be seen holistically to understand it (Aldwin, 2007; Folkman \& Moskwitz, 2004; Lazarus, 2006). In addition, it is necessary to take into account the particular and specific social context in which it occurs, as well as the broader context resulting in that important variable that is the culture (Díaz-Guerrero, 2003; 
Frydenberg et al., 2003; Góngora-Coronado, 2000; Wong \& Wong, 2006; Zeidner, 1994).

On the other hand, research has also shown that the high adaptability of human beings to various adverse situations in life, the daily ones or those of greatest difficulty, which translates into the ability to coping, is not something that is born with, but it is something that can be, and should be, improved throughout life (Kleinke, 1998). This led to another important aspect in the study of this concept, which is: How to know which the best ways to coping? And, on the other hand, how to promote or teach them? That is, to systematize forms of intervention.

In the development of the study of coping it is difficult to separate positive and negative forms. However some fairly systematic evidence has been found over time, and in different countries and cultures, that some strategies or emotion-oriented coping styles are related to some negative characteristics and younger age; and problem-oriented strategies, or task types, are associated with positive characteristics and older age (DeLongis \& Holtzman, 2005; Wong \& Wong, 2006; Zeidner, 1994).

Nonetheless, in recent times, it does not seem clearly what type of coping can be considered the best one, adaptively speaking (Skinner \& Zimmer-Gembeck, 2011).

On one hand, as the solution to the problem faced at a given time, and on the other, as the solution that contributes most to the psychological well-being and happiness of the person, as well as the most benefit, although this could not be seen at the moment. In this process, different types of coping with stress and adversity or problems have been identified in general that, in one way or another, seem to be the most positive, because the use of the strategies derived from them have proven to be the most effective when facing a problem or, in the possible effects in the personal well-being.

For example: 1) Positive reappraisal and adaptive coping (Folkman \& Moskwitz, 2004; Lazarus, 2006); 2) Problem-focused coping (Lazarus \& Folkman, 1984); 3) Coping with engagement (Skinner \& Zimmer-Gembeck, 2007); 4) Coping focused on meaning and cognitive restructuring of the problem (Folkman, 2008; Morling \& Evered, 2006); 5) Positive problem orientation (Nezu \& D’Zurilla, 1989; Vera-Villaroel \& Guerrero, 2003); 6) Proactive coping (Aspinwall \& Taylor 1997; Greenglass \& Fiksenbaum, 2009); and 7) Direct-reappraisal coping (Góngora-Coronado \& Reyes-Lagunes, 1999), among others, that in the majority are problem-oriented or solution-oriented. Nevertheless, this does not mean that other aspects are not important, for example, the management of emotions, which is fundamental as Lazarus constantly pointed out (Lazarus, 2006; Lazarus \& Folkman, 1984).

It is interesting how, in Mexican culture the Direct-reappraisal coping style, is found consistently in different studies and in different ages. This, both nationally (Reyes-Lagunes, 2011) and in a particular way in Yucatán (Góngora-Coronado \& Reyes-Lagunes, 1999, 2002; Góngora-Coronado, Flores-Galaz, Cortes-Ayala, 
Vásquez-Velázquez, \& Reyes-Lagunes, 2004; Góngora-Coronado, Reyes-Lagunes, Flores-Galaz, Cortés-Ayala, \& Iuit, 2007) coincides with the importance given by Díaz-Guerrero (1994) to reasoning, as the most convenient way to deal with problems in life. This type of coping combines searching the solution and thinking, analyzing, weighing the options, and taking into account the positive elements.

In this context, gradually, increasing attention has been given to the positive factors that can help to improve stress-adaptation relationship, and contribute to a better understanding of how some people have higher skills and chances of success and wellbeing in their encounter with stressful events (Aspinwall, 2011; Carver \& Scheier, 2002; Folkman \& Moskowitz, 2000; Fredrickson, 2002; Hobfoll, 2011; Seligman \& Csikszentmihalyi, 2000).

A closely related aspect to this point, which constitutes a new development in the field of coping, has to do with the growing awareness of the presence of positive emotions in the stress process (Stanton, Parsa, \& Austenfeld, 2002; Tugade, 2011; Zautra \& Reich, 2011). It would not only be the management of negative emotions in the face of problems or stress, but the approach that the joint occurrence of positive and negative emotions has important implications for the coping. The findings suggest that under stress situations people consciously seek the positive meaning of the events to pour it into the ordinary events in such a way that it gives them the strength to cope with the distress and helps them maximize their resources in coping (Folkman, 2008; Folkman \& Moskowitz, 2000).

Other variables of coping, that have been studied, are for instance: optimism (Carver \& Connor-Smith, 2009; Vera-Villaroel \& Guerrero, 2003), positive affect (Folkman \& Moskowitz, 2000), self-efficacy (Bandura, 2008) and perceived autonomy in goals (Sansinenea, Gil de Montes, Aguirrezabal, \& Garaigordobil, 2010). The concept of positive coping with life (Góngora-Coronado, 2010) would go in that direction, but with something extra, because it does not only occur in situations of stress or adversity, as originally defined, but: 1) at different life situations that may represent an effort, and 2) it would not only be to achieve an adaptation, but to bring out a plentiful life.

Therefore, it would mean changing the perception of difficult situations as problems or threats that people to have fought back, to challenges that can be overcome, and opportunities for learning something. That is, the emphasis would be on the "eutrés" (Selye, 1976) or the elements involved in hardy personality (Kobasa \& Pucceti, 1983) but with the view that this process is not only to be alive or exist but learning to live fully. This approach is near to what has been defined in philosophy as the art of living, and the good life, that is wisdom. The history of philosophy ("love of wisdom") has come long way in this sense (Marías, 1989). For philosophers such as Socrates, Plato and Aristotle, among others, wisdom was the highest level of reason and referred to as a theoretical wisdom (sophia) whose purpose was to reach the highest knowledge, and prac- 
tical wisdom (phronesis) which aimed to achieve a dignified and happy life (Marina, 2009).

However, psychology has also studied this concept quite broadly and its contribution would not only understand what it consists of from this psychological dimension, but on how to achieve it (Baltes, Glück, \& Kunzmann, 2002; Glück \& Baltes, 2006; Baltes \& Staundinger, 2000; Glück et al., 2013; Sternberg, 1998, 2004). And in this way, the approximation would exist, and at the same time the contribution of the concept of positive coping would reside; it would be like wisdom or practical intelligence, but in practice. It would involve applied ways of reaching it.

It is in this sense that in different areas in psychology (Baltes \& Freund, 2003; Baltes \& Smith, 2008; Baltes \& Staudinger, 2000; Sternberg, 1998) it has been argued that wisdom is like the mind or optimal human intelligence or ideal person trying to identify optimal strategies for coping with life. It would be like an aspiration of the human being in his process of optimal functioning (Seligman et al., 2016). That is, the knowledge of good and proper life (theoretical wisdom) and its implementation (practical wisdom) which would be a positive coping with life as an expression and fulfillment of the potential of human strengths.

It has been noted that, in the progress on the study of the concept of positive coping, in order to achieve a better adaptation to the different situations in life, it is necessary to think, feel and act holistically and purposefully (Góngora-Coronado, 2010). It does not help too much being passive spectators in the events that occur in life, but it is necessary to be key actors and protagonists (Bandura, 2001, 2008).

And this concept is framed in the context of positive psychology, understood as the scientific study of optimal human functioning, that has the purpose of expanding the interest of psychology beyond suffering and its consequent relief (Peterson \& Seligman, 2004; Seligman, 2002; Snyder \& López, 2007). It promotes strategies for people using their skills to enable them to achieve greater "flourishing" (Keyes \& Haidt, 2003; Seligman, 2011) in their lives. The assumption of all this, is the emphasis placed on the development of the potential of the human being in this process of coping, in the best possible way, with the different situations of life, that encourage him to live fully and not merely existing.

\subsection{Empirical Review}

Although current literature highlights the importance of the positive aspects of human beings or of the good life, and the benefits of it for health and well-being, there is still very little research on how to develop these skills and put them into practice (Eacott \& Frydenberg, 2009; Fordyce, 1977; Seligman, 2011). To do so in such a way, that they become a habit and a lifestyle that lead people to that full life or greater happiness promoted consistently by positive psychology. Although several intervention programs have been made about the concept of coping, mainly emphasizing negative aspects such as stress, power, anxiety, depression, anger or pain, among others (Bode et al., 2007; Lochman et al., 2012; McNally 
Keehn, Lincoln, Brown, \& Chavira, 2013; Yedigoz Sonmez \& Capri, 2013).

In order to fight the negative psychological symptoms that may occur in different populations and under different living situations such as illness or antisocial behaviors in adolescents and children. In the literature reviewed so far, there are few intervention proposals that have been carried out on coping in a positive context, practice and promotion of the path to happiness (Antoni, 2011; Eacott \& Frydenberg, 2009; Moskowitz, 2011). For example, some positive interventions on coping and mindfulness, and teaching meditation techniques to university students have been reported as part of a pilot program to test the feasibility of the program for the demands and needs of students (Lynch, Gander, Kohls, Kudielka, \& Walach, 2011). The design of programs about coping strategies for life in order to promote personal control of problem solving have also been reported (Hope \& Wellness Centre, n.d.) as well as promoting life skills (Pinto-Loría, Mena-May, \& Góngora-Coronado, 2012).

Regarding the methodology used for the various programs of coping, different activities and tasks have been carried out for a period of sessions in which topics related to the type of coping proposed by the program are addressed. For example, in the case of the coping power, the content is based on several studies about coping with anger and later systematic adjustments were made based on clinical evidence (Lochman et al., 2012). As for stress coping, there are interventions based on cognitive-behavioral techniques, and strategies based on clinical evidence and literature on coping with stress (Yedigoz Sonmez \& Capri, 2013).

Furthermore, intervention programs, about this concept reported in the literature that focuses on more positive psychological aspects. Some of them focus on topics such as problem solving and conflict of life and adaptation to different circumstances (Eacott \& Frydenberg, 2009; Pinto-Loria et al., 2012). They even consider coping and promoting mental health (Langeland, Wahl, Kristoffersen, \& Hanestad, 2007) but without explicitly addressing happiness and enjoyment of life when coping with problems and adversities of life; which is what that would be more related to a full life and with the proposal of one of the indicators of the construct of positive coping with life.

Taking into account the application of the principles of positive psychology to daily life and all the aforementioned, this research was carried out in three different studies in order to achieve a better approach to the nature of this construct (positive coping with life). On the one hand, to explore the aspects and behavior of a successful situation and difficult situations that have been solved in the best possible way; on the other hand, to identify the possible relationship with positive variables. To do so, variables that would be hypothetically related to its nature were included. Direct-Reappraisal coping was chosen as the representative indicator of this concept, which has proven to be the closest to a positive and adaptive meaning in a line of research (Góngora-Coronado, 2000; Góngora-Coronado \& Reyes-Lagunes, 1999; Reyes-Lagunes, 2011), as well as the positive variables of happiness, mindfulness and spirituality. Finally, an intervention program was designed. Its main objective was to systematize activities to 
develop a positive coping with life and to promote greater well-being and happiness in the participants.

\section{Method}

Since its inception, this study was developed with an integrating perspective, within the framework of a mixed methodology, which proposes an integration of quantitative and qualitative methods. Therefore, the methodological approach of this research work was based on the use of both qualitative (interviews) and quantitative (psychometric scales and laboratory equipment) techniques. The relevance of this methodological approach is that it offers a much broader perspective of the phenomenon to be studied and further enrichment of the information and data obtained. Similarly, it allows the integration of different viewpoints and provides greater validity to the results that may be obtained from the research (Clark \& Cresswell, 2008; Teddlie \& Tashakkori, 2009).

This research, as mentioned, was integrated into three phases. The first one it was a more qualitative phase, which included exploratory interviews. The second phase involved the application of psychometric instruments that measure positive psychological characteristics such as happiness, mindfulness and spirituality, and their relationship to the coping that has been considered the most positive so far, in the context of Mexican culture (direct-reappraisal) (Góngora-Coronado, 2000; Reyes-Lagunes, 2011). Finally, a third phase, which included the application of a pilot program of positive coping in two different contexts, college students and mothers with children having some condition of difficulty (addiction problems or autism spectrum).

\subsection{Participants}

\subsubsection{Phase 1}

The first phase was aimed at qualitatively exploring the nature of the concept of positive coping with life, through interviews. 50 people participated in this phase ( 25 men and 25 women) with a mean age of 25 years, residing in the city of Merida, Yucatan. The selection was by intentional non-probabilistic sampling.

\subsubsection{Phase 2}

This second phase aimed to identify if there was a statistically significant correlation between coping with life's problems and positive psychological characteristics such as happiness, spirituality and mindfulness. 153 people, 67 men and 86 women, participated. The aim was to identify the relationship between coping with life's problems and happiness, and spirituality variables. The mean age of this group was 35 ( $\mathrm{SD}=13.94)$. Furthermore, another sample was made to identify the relationship between coping with life and mindfulness. 153 high school students participated ( 74 women and 79 men) with a mean age of 15 years. Participants in both groups were living in the state of Yucatan, covering both the capital city and the interior of the state. 


\subsubsection{Phase 3}

This phase included the implementation of a program aimed to systematize the theoretical principles of positive coping with life with practice in ways that scientific research has shown to be important for a fuller and happier life. Two groups participated in this program: university students and two groups of parents with children with a special condition (16 participants): 1) drugs of abuse (11) and 2) autism spectrum (5). Regarding the university group, the number of participants was 16 ( 14 women and 2 men) with a mean age of 23 years, all of them were psychology students. All the participants were invited to participate in the program voluntarily.

\subsection{Instruments, Materials and Techniques}

\subsubsection{Phase 1}

To understand the experiences of people in this topic, a semi-structured interview was used, which consisted of the following questions and topics: a) Describe a success you have had, b) Could you describe what emotions you experienced in that situation? C) What do you think it had caused such success? D) Describe a difficult situation that you had to solve in the best way e) what emotions did you experience in that situation? f) What factors could have helped you solve such situation?

\subsubsection{Phase 2}

For this second phase, the following psychometric, culturally-relevant, and previously validated instruments were used:

a) The Subscale of Coping with life's problems of the Multidimensional and Multi-situational Styles of Coping Scale (Reyes-Lagunes \& Góngora-Coronado, 1998). This subscale has a reliability degree of 0.74 .

The full scale consists of six different situations (health, partner, family, friends, school or work, and life). Each situation consists of 18 Pictographic Likert type items, including seven response options ranging from always (7) to never (1) and where the following coping styles have appeared more consistently.

1) Direct-reappraisal (DR): When a person does something to solve the problem or trying to learn to see the positive in the situation.

2) Emotionally negative (EN): When a person expresses a feeling or an emotion that does not lead directly to the solution of the problem.

3) Evasive (EV): When a person tends to avoid or escape from the problem.

b) Scale of Happiness (Vásquez-Velázquez \& Góngora Coronado, 2012).

It is a pictographic type and it is composed of 21 items with five response options ranging from strongly agree (5) to strongly disagree (1). This scale of Happiness provided an internal consistency reliability of 0.83 among the factors.

It includes the following factors or dimensions:

1) Positive meaning to life (PMT). It refers to the positive attitudes and experiences toward life. It means that, happiness would be related to be free of deep 
depression and to have positive feelings toward themselves and toward life.

2) Satisfaction with life (SL). Expresses satisfaction at what has been achieved. The person believes that he is where he should be, or is close to achieving his ideal life.

3) Personal fulfillment (PF). Indicates self-sufficiency, emotional tranquility and peacefulness, which are necessary conditions for the state of complete happiness.

The concept of personal fulfillment corresponds with the definition of happiness which is the orientation of the individual toward goals that he considered valuable for life; this is an area which has been explored by other authors.

4) Joy of living (JL). Refers to how wonderful it is to live, positive life experiences, and feeling generally well.

5) Personal assessment (PA). This factor has to do with personal skills, that the individual not only acknowledge having, but also gives a degree of higher value over other skills. Possibly, this factor is related to self-esteem or a broader sense of personal value.

c) Spirituality Scale (Vásquez-Velázquez \& Góngora-Coronado, 2012).

It's also a pictographic type and it is composed of 22 items, with five response options ranging from strongly agree (5) to strongly disagree (1).

The spirituality scale provided a reliability of 0.85 .

Factors or dimensions included:

1) Positive states derived from spirituality (PSDS). Expresses emotional satisfaction or wellbeing states such as feeling at peace, strength, support.

2) Perception of spirituality (PS). Considers beliefs, thoughts, ideas and arguments concerning the nature and meaning of spirituality.

3)Spiritual Experiences (SE). Describes practices undertaken by people and the experiences they have had in this area, resulting from their spirituality.

d) Mindful Attention Awareness Scale (MAAS). Adapted and standardized by Soler et al. (2012) in a Spanish population. It has 15 items with a pictographic Likert scale types, with five response options ranging from almost always (5) to almost never (1).

\subsubsection{Phase 3}

To carry out the program, different instruments and techniques were used both to promote the positive coping with life and to evaluate it in a pre-post design. In addition to the scales used in phase 2, the scale of gratitude, validated in the context of Mexican culture (Góngora-Coronado, Jurado-Patrón, Pérez-Alonzo, \& Vásquez-Velázquez, 2014), was included as an exercise in this phase. This scale is unidimensional, pictographic and consists of four items with a range of 1 to 5 , with a reliability of 0.76

Activities to promote positive coping with life and happiness in the participants were also developed. Series of exercises based on the review of the scientific literature (Moskowitz, 2011; Moskowitz et al., 2012; Seligman, 2011) that have shown to have a major impact on the wellbeing, and for the optimal development 
of the people, were carried out. These exercises were distributed by topic in weekly sessions. In the same way, assignments outside the sessions were assigned, to reinforce the topics and to be applied to everyday life. A laboratory instrument that gave an immediate feedback (biofeedback) of the psycho-physiological processes related to training for relaxation and well-being, known as the Em wave, was also used.

\subsection{Procedure}

\subsubsection{Phase 1}

The application of semi-structured interviews was conducted individually in public places in the city of Merida, Yucatan or in private homes, and the participation of the people was requested on a voluntary basis. The interviews were recorded with the permission of the participants and later transcribed using the MSWord software. After that, a content analysis was carried out, according to the questions asked in the interview (Martínez-Miguélez, 2004).

\subsubsection{Phase 2}

For the implementation of these instruments, people were asked their consent to participate in the study. The instructions and relevant specifications were explained. The data was collected, and then the descriptive statistical analysis, and relevant correlations were carried out using the statistical program SPSS.

\subsubsection{Phase 3}

As for the delivery of the program, the exercises were distributed by topics and were covered in three-hour class sessions per week, making a total of fifteen sessions ( $45 \mathrm{hrs}$.) The following are some of the topics covered: Recognition of positive events, capitalization, positive reappraisal, personal strengths, positive emotions, positive coping, and happiness. The software "Em wave" was also used to exercise the participants in relaxation and well-being during short sessions in which they could see their progress on a screen.

\section{Results}

\subsection{Phase 1}

As a result of the content analysis of the participants (Martínez-Miguélez, 2004), the following findings were obtained, according to the frequency with which certain categories were mentioned:

Regarding successful situations reported by the people, those related to academic issues appeared more frequently, followed by those linked to personal fulfillment, success related to the family environment and the workplace, and finally, sporting achievements, awards or prizes, and romantic relationships. The emotions more frequently present in the successful situations are happiness and satisfaction. The next most frequently mentioned emotion was joy and pride.

Regarding attribution for success, effort seems to be the most important element to achieve it. One important element that draws attention in attributing 
success was affection or ties they have with other people such as friends, family, children, etc., this was above self-determination, which is the decision-making capacity of himself, to strive and achieve a goal or expectation. The difficult situations that people considered successfully resolved were most often related to family issues, followed by academic issues.

Regarding the emotions in difficult situations that were successfully resolved, the participants reported that happiness was the most common emotion, followed by peacefulness. The satisfaction generated by the achievement of the objectives was also reported as one of the highest emotions. Another most common emotion is related to the joy of reaching a goal, especially when this one is difficult.

Regarding the attribution of success in difficult situations, the main attribution is related to persistence-perseverance, in most cases it was observed that people kept striving to achieve their goals. The second most reported category was self-determination. Other popular categories were personal affection to others, planned action, in which a person makes an analysis to determine the importance of achievement and the steps to get it in a structured way, and finally the revaluation to solve the difficult situation in the best way.

Regarding the exploration and qualitative assessment, in the design before and after the intervention program, the responses comparatively interpreted were greater well-being, utility and satisfaction. Some of the responses were:

1) The experience in the course was positive, because in addition to deepening in Positive Psychology, it allowed me, above all, to put it into practice while giving me an opportunity for reflection and introspection.

2) I had the opportunity to realize that happiness is within oneself, it is not necessary to seek it out, but it is necessary to make the decision to cultivate it through actions, thoughts and feelings, to learn to see difficulties not as obstacles, but as opportunities and at the same time enjoy what you have instead of complaining about what you lack.

3) I learned the connection between mind and body and the way in which exercise and physical training such as relaxation and breathing are very important for emotional regulation, and if we practice it consistently it can help us in the task of being happy.

According to the results obtained, in this phase, both coping with the success situation and the difficult situation are attributed to similar indicators, since in the first case it was more effort, affection and family relationships and in the second it was attributed to perseverance and affection.

\subsection{Phase 2}

As it can be seen in Figure 1, in the quantitative approach, regarding the relationship between coping with life's problems and happiness, spirituality and mindfulness; some positive and significant correlations between some of the factors were found, but not between all of them, which confirms that are similar concepts in nature, but different in essence. As can also be seen in Figure 1, two 


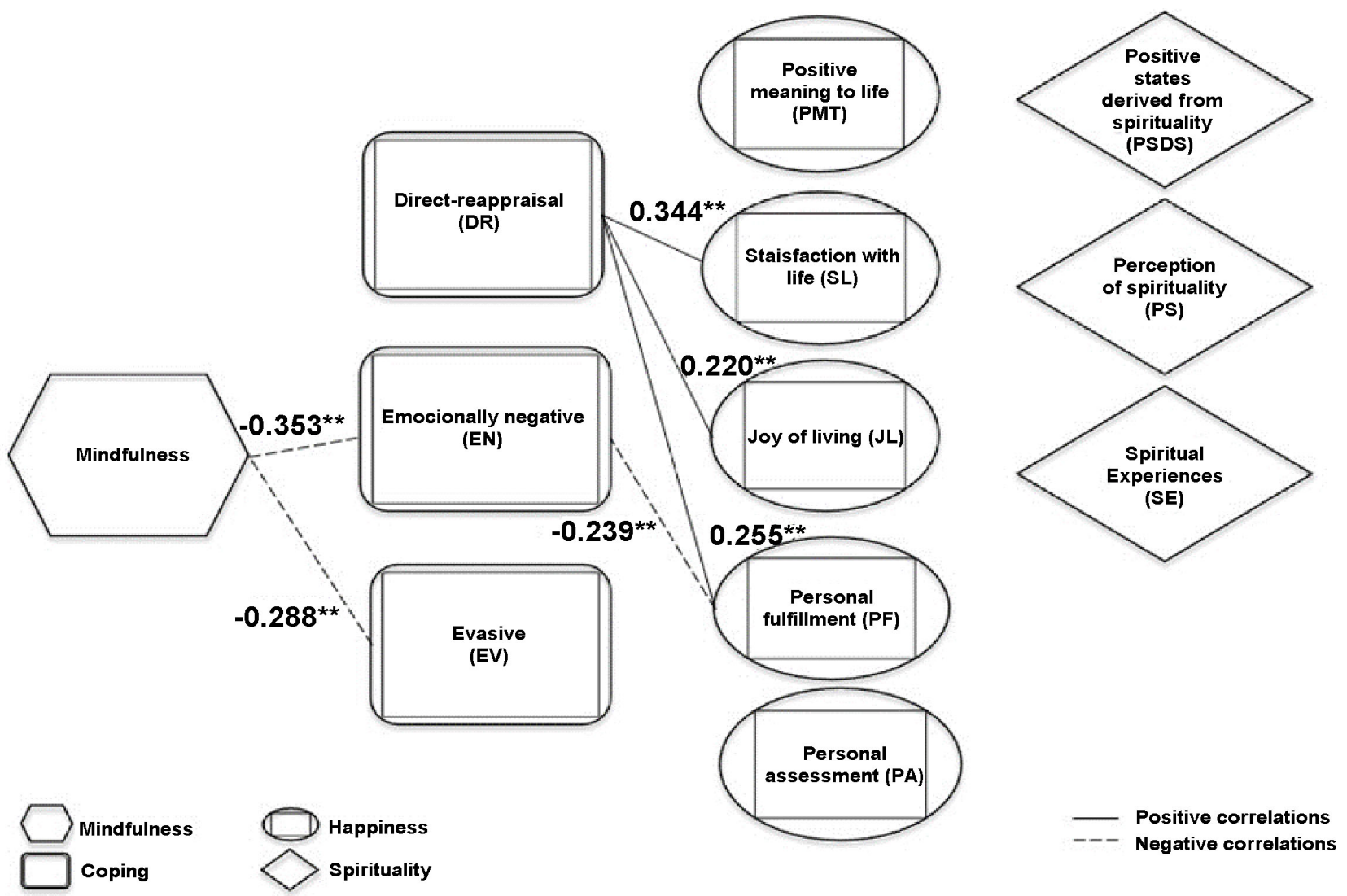

Figure 1. Significant correlations between coping, happiness, spirituality and mindfulness from participants.

of the three factors of coping with problems correlated negatively, and meaningfully with mindfulness; while three of the five happiness factors correlated in a theoretical logical sense with coping with problems. As can also be seen in Table 1, no significant correlations were found of coping with the problems, with any of the factors of the spirituality variable. However, significant correlations were found between all the factors of happiness and spirituality (Vásquez-Velázquez \& Góngora-Coronado, 2012).

In this phase quantitative, almost in all cases, the scores were above the theoretical average, except for the case of the spiritual experiences factor. Regarding the correlations, the significant correlations are logical from the theoretical point of view, both in the positive and in the negative sense. Although the variable of mindfulness, correlated negatively with the negative emotional and with the evasive, however, it does not correlate significantly with the direct-reappraisal and the variable of spirituality did not correlate with any of the factors of coping.

In phase 3, a difference analysis was carried out for which the non-parametric Wilcoxon test was used in order to evaluate the differences before and after the intervention program. It was found, as can be seen in Table 1, that significant differences were obtained in most of the variables studied, in the sense of positive improvement, because 9 of 13 possibilities were found significant.

In the positive sense that is, of improvement in the different factors or variables, they suggest that the program did meet its objective. 
Table 1. Analysis of differences with the Wilcoxon test to evaluate the pre-post differences of the intervention program of the studied sample.

\begin{tabular}{|c|c|c|c|c|c|c|}
\hline Variables & Factores & $N$ & Mean-pre & Mean-post & $t$ & Sig. \\
\hline \multirow[t]{3}{*}{ Coping } & Direct-reappraisal & 29 & 6.0510 & 6.2414 & -1.27 & 0.214 \\
\hline & Emotionally negative & 29 & 4.9224 & 4.0948 & 3.80 & 0.001 \\
\hline & Evasive & 29 & 3.5893 & 3.2232 & 1.70 & 0.101 \\
\hline Mindfulness & Unifactorial & 29 & 3.8644 & 4.0782 & -2.16 & 0.039 \\
\hline Gratitude & Unifactorial & 29 & 4.2299 & 4.5000 & -1.46 & 0.153 \\
\hline \multirow[t]{5}{*}{ Happiness } & Positive meaning to life & 29 & 4.1724 & 4.4621 & -2.42 & 0.022 \\
\hline & Satisfaction with life & 29 & 3.9138 & 4.3793 & -3.95 & 0.000 \\
\hline & Personal fulfillment & 29 & 4.0345 & 4.2845 & -1.90 & 0.067 \\
\hline & Joy of living & 29 & 4.0000 & 4.3908 & -2.99 & 0.006 \\
\hline & Personal assessment & 29 & 3.8276 & 4.1954 & -3.41 & 0.002 \\
\hline \multirow[t]{3}{*}{ Spirituality } & $\begin{array}{l}\text { Positive states derived } \\
\text { from spirituality }\end{array}$ & 29 & 3.7552 & 4.1429 & -3.81 & 0.001 \\
\hline & Perception of spirituality & 29 & 4.0612 & 4.3214 & -2.99 & 0.006 \\
\hline & Spiritual experiences & 29 & 2.6929 & 3.1172 & -3.08 & 0.005 \\
\hline
\end{tabular}

\section{Discussion}

As mentioned in the literature, the review of the concept of coping with stress, problems or adversity has evolved during the course of its study, from a more individual approach to focusing on the negative (Billings \& Moos, 1981, 1984; Endler \& Parker, 1990; Lazarus \& Folkman, 1984; McCrae, 1984; Pearlin \& Shooler, 1978) to a more comprehensive approach, broad, socio-cultural and with emphasis on the positive (Aldwin, 2007; Díaz-Guerrero, 2003; Folkman \& Moskowitz, 2004; Frydenberg et al., 2003; Góngora-Coronado, 2000).

In this paper, the concept of positive coping with life is addressed (Góngora-Coronado, 2010), in the context of positive psychology (Lopez \& Snyder, 2009; Pawelski \& Moores, 2013; Seligman, 2002, 2011; Seligman et al., 2016), as a form of practical wisdom to coping the different situations of life, and that would not only occur in situations of stress or adversity, as the original definition of this concept, nor as adaptation, but to promote a fuller life, that is, to advance on the path of happiness, with the vision that this process is not only to survive but to learn to live life to the full.

Therefore, as mentioned before, this proposal of positive coping with life approach is more related to philosophy has been defined as the art of living and a good life, that is, wisdom, and more specifically the practical wisdom (Marías, 1989; Marina, 2009) and has also been mentioned in psychology (Aldwin, 2011) although, in this case, not with an explicit emphasis on a full life.

This work was developed in the context of positive psychology, it comprises on its meaning the concept of wisdom or practical intelligence studied in psychology (Baltes et al., 2002; Glück \& Baltes, 2006; Baltes \& Staundinger, 2000; 
Glück et al., 2013; Sternberg, 1998, 2004). The emphasis is on how this positive coping with life would be an adequate way to move toward happiness and a full life and not only the adaptation.

Taking into account that an important function of positive psychology is to provide scientific elements to learn about good things, this study was complemented with an intervention program, based on studies that also point to the importance of the implementation of practical exercises related to the coping (Eacott \& Frydenberg, 2009; Fordyce, 1977; Moskowitz et al., 2012); so that the participants systematically practiced how to positively cope with different daily situations in life.

Principles of positive psychology were retaken, that positive strengths and qualities can be learned, but it is necessary to practice them to achieve optimal human functioning (Peterson \& Seligman, 2004; Snyder \& López, 2007). This study goes is meant to promote strategies for people using their skills to enable them to achieve a greater flourishing (Keyes \& Haidt, 2003; Seligman, 2011) in their lives, for the development of human potential in the process of facing the best possible way the different life situations that encourage you to live life in full. It goes on to develop active and proactive human beings, before the events that occur in life, to become the main actors and players in it (Bandura, 2001).

The results of this intervention program confirmed that the systematization and practice produce learning toward the path to happiness and well-being, as the results of the pre-post design test as well as the qualitative approach clearly show, that they are favorable changes in this learning. The activities programed appear adequate to promote positive coping and happiness. One of the evident strengths of the exercises was their simplicity, because they allow participants to apply them in contexts different to the sessions, and especially in their daily lives.

This research was carried out with this point of view, in a first phase to explore the nature of positive coping with life, in a qualitative way. In a second one, to study the relation of direct-reappraisal coping, which has been seen as the most approach in the context of Mexican culture (Góngora-Coronado \& Reyes-Lagunes, 1999, 2002; Góngora-Coronado et al., 2004, 2007; Reyes-Lagunes, 2011), with happiness, mindfulness and spirituality, which are positive variables, in order to explore more precisely the nature of the concept of positive coping with life. And in a third phase, the objective was to search for a systematization of strategies to exercise and practice a better learning of a more positive type of coping.

In this context, according to the results obtained, in phase 1 (qualitative), it is important to point out that both coping with the success situation and the difficult situation are attributed to similar indicators, since in the first case it was more effort, affection and family relationships and in the second it was attributed to perseverance and affection. Which coincides with the importance given in these cases of coping with demanding situations, to the efforts of the person and to the relationships with people close to them, or to whom one has affection 
such as the family.

In phase 2 (quantitative) it is pertinent to point out that almost in all cases, the scores were above the theoretical average, since only in one case, which was the spiritual experiences factor of the spirituality variable, was slightly below the average.

Regarding the correlations, as mentioned in the results section, the significant correlations are logical from the theoretical point of view, both in the positive and in the negative sense. For example, the fact that the direct reappraisal factor of coping with problems correlate positively with the factors of satisfaction with life, joy of life, and personal fulfillment on the one ; and the negative emotional coping will correlate negatively with the latter. Personal achievement, has a theoretical logic since the first ones implies more action to address the situation, trying to find a meaning or learn from it, and the second one involves negative emotions that do not lead to the solution of the problem, and that it would go in the opposite direction to the factor of personal fulfillment of happiness.

So far the weight of the interpretation would be more in the sense that people who use more the type of direct-reappraisal coping tend to be happier, while those who use more the negative emotional type, would have less of this factor of happiness, which is personal fulfillment, that confirms the results of previous studies, it means that it has positive aspects (Góngora-Coronado, 2000; Góngora-Coronado et al., 2004, 2007; Reyes-Lagunes, 2011).

On the other hand, the variable of mindfulness, which implies full attention in the present to enjoy a certain situation of life, correlates negatively with the negative emotional and with the evasive, which are types of coping more of a negative nature, which also has a theoretical logic. However, this psychological variable does not correlate significantly with the direct-reappraisal, which could be indicating that this type of coping, although it has a positive character, does not necessarily have that aspect of enjoying life. What confirms this interpretation even more is that the variable of spirituality did not correlate with any of the factors of coping, which could be interpreted in the sense that the concept of spirituality implies a state of transcendence, rather than a real and concrete situation, which would be more the case of coping.

Regarding the results of the intervention program, the fact that in the analysis of differences between the pre-situation and the post-situation, there were 9 out of 13 possible significant differences. In the positive sense that is, of improvement in the different factors or variables, they suggest that the program did meet its objective. That is, the people who participated in this program increased their positive characteristics or reduced the negative ones. This happened both for coping with problems, as well as for spirituality and Mindfulness. Another point that seems to be important in the program is the fact that it has lasted for a considerable time (5 months), which provided for knowledge to be reinforced in each of the sessions and evaluated on their application and effectiveness during the week.

It can also be said that this course may provide the participants with the tools 
for, both, training and personal growth, and for their performance as professionals. Regarding the nature of the activities, the participants said that seemed attractive, practical and could be related to their lives in their exercise to be happy.

\section{Conclusions}

First, it can be concluded that the most positive factor of the concept of coping with stress, problems or adversity is the direct-reappraisal (Góngora-Coronado, 2000; Góngora-Coronado \& Reyes-Lagunes, 1999, 2002; Góngora-Coronado et al., 2004; Góngora-Coronado et al., 2007; Reyes-Lagunes, 2011), it seems to have a theoretical and empirical relationship with happiness, which means an approximation to the stated objective, although it was not the same with mindfulness and spirituality. These results can serve as a motivation to study the concept of positive coping with life in a more systematic way, which involves coping with the demanding situation, be it stressful or significant, in the best way, but enjoying life at the same time (Góngora-Coronado, 2010).

Second, based on the results of the intervention program, it can be said that important objectives were achieved by favorable testimonies of participants, both with satisfaction for having taken such as increased awareness of taking advantage of many opportunities in life to be happier, and the willingness to try it; with the conviction that happiness is possible and the road can be, largely, coping positively with life, not only to become stronger and reassess the hardest and situations with greater adversity, but also to use and value the good things that occur in life can make it more enjoyable and plentiful.

Third, according to the results of this study it can be confirmed that the task of being happy is an activity that can be achieved through training and dedication, and in this case through the practice around a specific concept such as positive coping with life. There are tasks and exercises applied to life to achieve this goal, and that the person need to: a) make the decision to do so, b) have the confidence that it can be achieved, and c) take the opportunity to carry it out.

Fourth, it would also be confirmed that it is possible to link the principles of science about what is good, in everyday life with its systematic application, in learning positive coping to life, for the fulfillment of one of the most important tasks, which is to be happy.

\section{Conflicts of Interest}

The authors declare no conflicts of interest regarding the publication of this paper.

\section{References}

Aldwin, C. M., \& Revenson, T. A. (1987). Does Coping Help? A Reexamination of the Relation between Coping and Mental Health. Journal of Personality and Social Psychology, 53, 337-348. https://doi.org/10.1037/0022-3514.53.2.337

Aldwin, M. C. (2007). Stress, Coping and Development. An Integrative Perspective. New York: The Guilford Press. 
Aldwin, M. C. (2011). Stress and Coping across the Lifespan. In S. Folkman (Ed.), The Oxford Handbook of Stress, Health, and Coping (pp. 15-34). New York: Oxford University Press.

Antoni, M. H. (2011). Stress, Coping, and Health in HIV/AIDS. In S. Folkman (Ed.), The Oxford Handbook of Stress, Health and Coping (pp. 428-449). New York: Oxford University.

Aspinwall, L. G. \& Taylor, S. E. (1997). A Stitch in Time: Self-Regulation and Proactive Coping. Psychology Bulletin, 121, 417-436. https://doi.org/10.1037/0033-2909.121.3.417

Aspinwall, L. G. (2011). Future-Oriented Thinking, Proactive Coping, and the Management of Potential Threats to Health and Well-Being. In S. Folkman (Ed.), The Oxford Handbook of Stress, Health and Coping, (pp. 334-365). New York: Oxford University Press.

Baltes, P. B., \& Freund, A. M. (2003). The Intermarriage of Wisdom and Selective Opimization with Compensation: Two Meta-Heuristics Guiding the Conduct of Life. In C. L. M. Keyes \& J. Haidt (Eds.), Fluorishing. Positive Psychology and the Life Well-lived (pp. 249-273). Washington, DC: APA. https://doi.org/10.1037/10594-011

Baltes, P. B., \& Smith, J. (2008). The Fascination of Wisdom. Its Nature, Ontogeny, and Function. Perspectives on Psychological Science, 3, 56-64.

https://doi.org/10.1111/j.1745-6916.2008.00062.x

Baltes, P. B., \& Staudinger, U. (2000). Wisdom: A Metatheuristic (Pragmatic) to Orchestrate Mind and Virtue toward Excellence. American Psychologist, 55, 122-136. https://doi.org/10.1037/0003-066X.55.1.122

Baltes, P. B., Glück, J., \& Kunzmann, U. (2002). Wisdom: Its Structure and Function in Regulating Successful Lifespan Development. In C. R. Snyder, \& S. J. Lopez (Eds.), Handbook of Positive Psychology (pp. 327-347). New York: Oxford University Press.

Bandura, A. (2001). Social Cognitive Theory: An Agentic Perspective. Annual Review of Psychology, 52, 1-26. https://doi.org/10.1146/annurev.psych.52.1.1

Bandura, A. (2008). An Agentic Perspective on Positive Psychology. In S. J. Lopez (Ed.), Positive Psychology: Exploring the best in people. Volume I (pp. 167-196). Wesport, CT: Greenwood Publishing Company.

Billings, A. G., \& Moos, R. H. (1981). The Role of Coping Responses and Social Resources in Attenuating the Stress of Life Events. Journal of Behavioral Medicine, 4, 139-157. https://doi.org/10.1007/BF00844267

Billings, A. G., \& Moos, R. H. (1984). Coping, Stress, and Social Resources among Adults with Unipolar Depression. Journal of Personality and Social Psychology, 46, 877-891. https://doi.org/10.1037/0022-3514.46.4.877

Bode, C., de Ridder, D. T. D., Kuijer, R. G., \& Bensing, J. M. (2007). Effects of an Intervention Promoting Proactive Coping Competencies in Middle and Late Adulthood. The Gerontologist, 47, 42-51. https://doi.org/10.1093/geront/47.1.42

Buskits, W. F., \& Davis, S. F. (Eds.) (2007). Health Psychology. 21st Century Psychology: A Reference Handbook. Thousand Oaks, CA: SAGE Publications.

Carver, C. S., \& Connor-Smith, J. (2009). Personality and Coping. Annual Review of Psychology, 61, 679-704. https://doi.org/10.1146/annurev.psych.093008.100352

Carver, C. S., \& Scheier, M. F. (2002). Optimism. In C. R. Snyder, \& S. J. López (Eds.), Handbook of Positive Psychology (pp. 231-243). New York: Oxford University Press.

Clark, V. P., \& Creswell, J. (2008). The Mixed Methods Reader. MI: SAGE Publishing.

Csikszentmihalyi, M., \& Csikzsentmihalyi, I. S. (2006). A Life Worth Living: Contribu- 
tions to Positive Psychology (Series in Positive Psychology). New York: Oxford University Press.

DeLongis, A., \& Holtzman, S. (2005). Coping in Context: The Role of Stress, Social Support, and Personality in Coping. Journal of Personality, 73, 1633-1659. https://doi.org/10.1111/j.1467-6494.2005.00361.x

Díaz-Guerrero, R. (1994). Psicología del mexicano. Descubrimiento de la etnopsicología. México: Trillas.

Díaz-Guerrero, R. (2003). Bajo las garras de la cultura. Psicología del mexicano 2. México: Trillas.

Eacott, C., \& Frydenberg, E. (2009). Promoting Positive Coping Skills for Rural Youth: Benefits for At-Risk Young People. Australian Journal of Rural Health, 17, 338-345. https://doi.org/10.1111/j.1440-1584.2009.01109.x

Endler, N. S., \& Parker, J. D. A. (1990). Multidimensional Assessment of Coping: A Critical Evaluation. Journal of Personality and Social Psychology, 58, 844-854. https://doi.org/10.1037/0022-3514.58.5.844

Folkman, S., \& Lazarus, R. (1980). An Analysis of Coping in a Middle-Aged Community Sample. Journal of Health and Social Behavior, 21, 219-239. https://doi.org/10.2307/2136617

Folkman, S., \& Moskowitz, J. T. (2000). Positive Affect and the Other Side of Coping. American Psychologist, 55, 647-654. https://doi.org/10.1037/0003-066X.55.6.647

Folkman, S., \& Moskowitz, J. T. (2004). Coping: Pitfalls and Promise. Annual Review of Psychology, 55, 745-774. https://doi.org/10.1146/annurev.psych.55.090902.141456

Folkman, S. (1984). Personal Control and Stress and Coping Processes: A Theoretical Analysis. Journal of Personality and Social Psychology, 46, 839-852.

https://doi.org/10.1037/0022-3514.46.4.839

Folkman, S. (2008). The Case for Positive Emotions in the Stress Response. Anxiety, Stress, \& Coping, 21, 3-14. https://doi.org/10.1080/10615800701740457

Folkman, S. (2011). Stress, Health, and Coping: An Overview. In S. Folkman (Ed.), The Oxford Handbook of Stress, Health and Coping (pp. 3-11). USA: Oxford University.

Fordyce, M. W. (1977). Development of a Program to Increase Personal Happiness. Journal of Counseling Psychology, 24, 511-521.

https://doi.org/10.1037/0022-0167.24.6.511

Fredrickson, B. (2002). Positive Emotions. In C. R. Snyder, \& S. J. Lopez (Eds.), Handbook of Positive Psychology (pp. 120-134). US: Oxford University.

Frydenberg, E., Lewis, R., Kennedy, G., Ardila, R., Frindte, W., \& Hannoun, R. (2003). Coping with Concerns: An Exploratory Comparison of Australian, Colombian, German, and Palestinian Adolescents. Journal of Youth and Adolescence, 32, 59-69. https://doi.org/10.1023/A:1021084524139

Glück, J., \& Baltes, P. B. (2006). Using the Concept of Wisdom to Enhance the Expression of Wisdom Knowledge: Not the Philosopher's Dream, but Differential Effects of Developmental Preparedness. Psychology and Aging, 21, 679-690.

https://doi.org/10.1037/0882-7974.21.4.679

Glück, J., König, S., Naschenweng, K., Redzanowski, U., Dorner, L., \& Straßer, I. (2013). How to Measure Wisdom: Content, Reliability and Validity of Five Measures. Frontiers in Psychology, 4, 12.

Góngora-Coronado, E. A. (2000). El enfrentamiento a los problemas y el papel del control. Una visión etnopsicológica en un ecosistema con tradición. Tesis no publicada 
de doctorado, México: Universidad Nacional Autónoma de México.

Góngora-Coronado, E. A. (2010). El enfrentamiento a los problemas vs. el enfrentamiento positivo a la vida. In M. M. Flores Galaz (Ed.), Aportaciones a la psicología social y comunitaria en Yucatán. Universidad Autónoma de Yucatán.

Góngora-Coronado, E. A., Flores-Galaz, M. M., Cortés-Ayala, M. L., Vásquez-Velázquez, N., \& Reyes-Lagunes, I. (2004). El enfrentamiento a los problemas en niños: Una aproximación a su estudio en escolares yucatecos. La Psicología Social en México, X, 17-24.

Góngora-Coronado, E. A., Jurado-Patrón, D. L., Pérez-Alonzo, J. G., \& Vásquez-Velázquez, I. I. (2014). La psicología social en México, 10 (pp. 17-24). México: AMEPSO.

Góngora-Coronado, E. A., \& Reyes-Lagunes, I. (1999). La Estructura de los Estilos de Enfrentamiento: Rasgo y Estado en un Ecosistema Tradicional Mexicano. Revista Sonoronse de Psicología, 13, 3-14.

Góngora-Coronado, E. A., \& Reyes-Lagunes, I. (2002). El estudio al enfrentamiento a los problemas: Una opción al dilema: Ética Vs. Control Experimental. La Psicología Social en México. IX, 896-902. México: AMEPSO.

Góngora-Coronado, E. A., Reyes-Lagunes, I., Flores-Galaz, M., Cortés-Ayala, \& Iuit-Briceño, J. (2007). Hacia la validación de una prueba para medir el enfrentamiento a los problemas en niños. XXXI Congreso Interamericano de psicología, México, D.F., 1-5 de Julio.

Greenglass, E. R., \& Fiksenbaum, L. (2009). Proactive Coping, Positive Affect and Well-Being. European Psychologist, 14, 29-39. https://doi.org/10.1027/1016-9040.14.1.29

Hobfoll, S. E. (2011). Conservation of Resource Theory: Its Implication for Stress, Health and Resilience. In S. Folkman (Ed.), The Oxford Handbook of Stress, Health and Coping (pp. 127-147). New York: Oxford University Press.

Holahan, C. J., \& Moos, R. H. (1990). Life Stressors Resistance Factors, and Improved Psychological Functioning: An Extension of the Stress Resistance Paradigm. Journal of Personality and Social Psychology, 58, 909-917. https://doi.org/10.1037/0022-3514.58.5.909

Keyes, L. M., \& Haidt, J. (2003). Introduction: Human Flourishing. The Study of That Which Makes Life Worthwhile. In C. L. M. Keyes, \& J. Haidt (Eds.), Flourishing: Positive Psychology and the life Well-Lived (pp. 3-12). EU: APA.

Kleinke, C. L. (1998). Coping with Life Challenges. USA: Brooks Cole.

Kobasa, S. C., \& Puccetti, M. C. (1983). Personality and Social Resources in Stress Resistance. Journal of Personality and Social Psychology, 45, 839-850. https://doi.org/10.1037/0022-3514.45.4.839

Langeland, E., Wahl, A., Kristoffersen, K., \& Hanestad, B. (2007). Promoting Coping: Salutogenesis among People with Mental Health Problems. Issues in Mental Health Nursing, 28, 275-295. https://doi.org/10.1080/01612840601172627

Latack, J. C., \& Havlovic, S. J. (1992). Coping with Job Stress: A Conceptual Evaluation Framework for Coping Measures. Journal of Organizational Behavior, 13, 479-508. https://doi.org/10.1002/job.4030130505

Lazarus, R., \& Folkman, S. (1984). Stress, Appraisal and Coping. New York: Springer.

Lazarus, R. (2006). Emotions and Interpersonal Relationships: Toward a Person-Centered Conceptualization of Emotions and Coping. Journal of Personality, 74, 9-46. https://doi.org/10.1111/j.1467-6494.2005.00368.x

Lochman, J. E., Powell, N., Boxmeyer, C., Andrade, B., Stromeyer, S. L., \& Jimenez, L. A. 
(2012). Adaptations to the Coping Power Program's Structure, Delivery Settings and Clinician Training. Psychotherapy, 49, 135-142. https://doi.org/10.1037/a0027165

Lopez, S., \& Snyder, C. (Eds.) (2009). The Oxford Handbook of Positive Psychology. New York: Oxford University Press.

Lynch, S., Gander, M., Kohls, N., Kudielka, B., \& Walach, H. (2011). Mindfulness-Based Coping with University Life: A Non-Randomized Wait-List-Controlled Pilot Evaluation. Stress and Health, 27, 365-375. https://doi.org/10.1002/smi.1382

Marías, J. (1989). Historia de la Filosofía. México: Patria.

Marina, J. A. (2009). El aprendizaje de la sabiduría. Aprender a vivir/Aprender a convivir. Barcelona: Ariel.

Martínez-Miguélez, M. (2004). Ciencia y arte en la metodología cualitativa. México: Trillas.

McCrae, R. R. (1984). Situational Determinants of Coping Responses: Loss, Threat, and Challenge. Journal of Personality and Social Psychology, 46, 919-928. https://doi.org/10.1037/0022-3514.46.4.919

McNally Keehn, R., Lincoln, A., Brown, M., \& Chavira, D. (2013). The Coping Cat Program for Children with Anxiety and Autism Spectrum Disorder: A Pilot Randomized Controlled Trial. Journal of Autism and Developmental Disorders, 43, 57-67. https://doi.org/10.1007/s10803-012-1541-9

Morling, B., \& Evered, S. (2006). Secondary Control Reviewed and defined. Psychological Bulletin, 132, 269-296. https://doi.org/10.1037/0033-2909.132.2.269

Moskowitz, J. T. (2011). Coping Interventions and the Regulation of Positive Affect. In S. Folkman (Ed.), The Oxford Handbook of Stress, Health and Coping (pp. 407-427). USA: Oxford University.

Moskowitz, J. T., Hult, J. R., Duncan, L. G., Cohn, M. A., Maurer, S., Bussolari, C., \& Acree, M. (2012). A Positive Affect Intervention for People Experiencing Health-Related Stress: Development and Non-randomized Pilot Test. Journal of Health Psychology, 17, 676-692. https://doi.org/10.1177/1359105311425275

Nezu, A. M., \& D’Zurilla, T. J. (1989). Social Problem Solving and Negative Affective Conditions. In P. C. Kendall, \& D. Watson (Eds.), Anxiety and Depression: Distinctive and Over Lapping Features (pp. 285-315). New York: Academic Press.

Pawelski, J. O., \& Moores, D. J. (2013). The Eudaimonic Turn: Well-Being in Literary Studies. Madison, NJ: Fairleigh Dickinson University Press.

Pearlin, L. I., \& Schooler, C. (1978). The Structure of Coping. Journal of Health and Social Behavior, 19, 2-21. https://doi.org/10.2307/2136319

Peterson, C., \& Seligman, M. (2004). Character Strengths and Virtues. A Handbook and Classification. Oxford: Oxford University Press.

Pinto-Loría, M. L., Mena-May, G. B., \& Góngora-Coronado, E. A. (2012). Enfrentándome a la vida. Manejo de Problemas y Conflictos con el enfoque de habilidades para la vida OPS/OMS. Manual del Facilitador. México: Universidad Autónoma de Yucatán.

Rabinowitz, A. R., \& Arnett, P. A. (2013). Coping in Neurological Disorders. In J. J. Randolph (Ed.), Positive Neuropsychology: Evidence Based Perspective on Promoting Cognitive Health (pp. 13-24). New York: Springer. https://doi.org/10.1007/978-1-4614-6605-5_2

Reyes-Lagunes, I. (2011). Conceptuación y desarrollo de la etnopsicometría en México. En A. Domínguez Espinosa (comp.). In A. Domínguez Espinosa (comp.), Lecturas introductorias a la psicología cultural, transcultural y etnospsicología (pp. 279-302). 
México: Universidad Iberoamericana.

Reyes-Lagunes, I., \& Góngora-Coronado, E. A. (1998). Escala multidimensional y multisituacional de enfrentamiento a los problemas. Proyecto CONACYT, 1084. PH. Universidad Nacional Autónoma de México.

Sansinenea, E., Gil de Montes, L., Aguirrezabal, A., \& Garaigordobil, M. (2010). Predictores del afecto positivo: el papel de la autonomía percibida y el estilo de enfrentamiento. Ansiedad y Estrés, 16, 71-82.

Scheier, M. F., Carver, C. S., \& Bridges, M. W. (1994). Distinguishing Optimism from Neuroticism (and Trait Anxiety, Self-Mastery, and Self-Esteem): A Reevaluation of the Life Orientation Test. Journal of Personality and Social Psychology, 67, 1063-1078. https://doi.org/10.1037/0022-3514.67.6.1063

Seiffge-Krenke, I. (2011). Coping with Relationship Stressors: A Decade Review. Journal of Research on Adolescence, 21, 196-210. https://doi.org/10.1111/j.1532-7795.2010.00723.x

Seligman, M. E. P. (2002). Authentic Happiness. New York: Free Press.

Seligman, M. E. P. (2011). La vida que florece. Barcelona: Ediciones B.

Seligman, M. E. P., \& Csikszentmihalyi, M. (2000). Positive Psychology. American Psychologist, 55, 5-14. https://doi.org/10.1037/0003-066X.55.1.5

Seligman, M., E., P., Railton, P., Baumeister, R., \& Sripada, C. (2016). Homo Prospectus. Oxford: University Press.

Selye, H. (Ed.) (1976). The Stress of Life. New York: McGraw-Hill.

Skinner, E. A., \& Zimmer-Gembeck, M. J. (2007). The Development of Coping. Annual Review of Psychology, 58, 119-144. https://doi.org/10.1146/annurev.psych.58.110405.085705

Skinner, E. A., \& Zimmer-Gembeck, M. J. (2011). Perceived Control and the Development of Coping. In S. Folkman (Ed.), The Oxford Handbook of Health, Stress and Coping (pp. 35-62). New York: Oxford University.

Snyder, C. R., \& López, S. J. (Eds.) (2002). Handbook of Positive Psychology. New York: Oxford University.

Snyder, C. R., \& López, S. J. (Eds.) (2007). Positive Psychology. The Scientific ad Practical Explorations of Human Strengths. New York: Oxford University.

Soler, J., Tejedor, R., Feliu-Soler, A., Pascual, J., Cebolla, A., Soriano, J., Alvarez, E., \& Pérez, V. (2012). Propiedades psicométricas de la versión española de la escala Mindful Attention Awareness Scale (MASS). Actas Españolas de Psiquiatría, 40, 18-25.

Stanton, A. L., Parsa, A., \& Austenfeld, J. L. (2002). The Adaptive Potential of Coping through Emotional Approach. In C. R. Snyder, \& S. J. López (Eds.), Handbook of Positive Psychology (pp. 231-243). New York: Oxford University Press.

Sternberg, R. J. (1998). A Balance Theory of Wisdom. Review of General Psychology, 2, 347-365. https://doi.org/10.1037/1089-2680.2.4.347

Sternberg, R. J. (2004). Why Smart People Can Be So Foolish. European Psychologist, 9, 145-150. https://doi.org/10.1027/1016-9040.9.3.145

Stone, A., \& Neale, J. (1984). New Measure of Daily Coping Development and Preliminary Results. Journal of Personality and Social Psychology, 46, 892-906. https://doi.org/10.1037/0022-3514.46.4.892

Teddlie, C., \& Tashakkori, A. (2009). Foundations of Mixed Methods Research. Integrating Quantitative and Qualitative Approaches in the Social and Behavioral Sciences. USA: SAGE Publishing. 
Tugade, M. M. (2011). Positive Emotions, Coping, \& Resilience. In S. Folkman (Ed.), Handbook of Stress, Health, and Coping (pp. 186-199). New York: Oxford University Press.

Vásquez-Velázquez, I. I., \& Góngora-Coronado, E. A. (2012). Explorando relaciones y diferencias ¿Son más felices las personas espirituales? In Presencia Psicológica. Aportes de investigación psicológica. Volumen I (pp. 173-229).

Vera-Villaroel, P., \& Guerrero, A. (2003). Diferencias en habilidades de resolución de problemas sociales en sujetos optimistas y pesimistas. Universitas Psychologica, 2, 21-26.

Wong, P. T. P., \& Wong, L. C. J. (Eds.) (2006). Handbook of Multicultural Perspectives on Stress and Coping. US: Springer-Science. https://doi.org/10.1007/b137168

Yedigoz Sonmez, G., \& Capri, B. (2013). The Effect of Stress Coping Program on Burnout Levels of High School Students. International Journal on New Trends in Education and Their Implications, 4, 148-164.

Zautra, A., \& Reich, J. (2011). Resilience: The Meanings, Methods and Measures of a Fundamental Characteristic of Human Adaptation. In Handbook on Stress, Health and Coping. Oxford: Oxford University Press.

Zeidner, M. (1994). Personal and Contextual Determinants of Coping and Anxiety in an Evaluative Situation: A Prospective Study. Personality and Individual Differences, 16, 899-918. https://doi.org/10.1016/0191-8869(94)90234-8 